\title{
Intrathecal synthesis of antibodies to HTLV-III in patients without AIDS or AIDS related complex
}

\author{
J GOUDSMIT, E C WOLTERS, M BAKKER, L SMIT, J VAN DER NOORDAA, \\ E A H HISCHE, J A TUTUARIMA, H J VAN DER HELM
}

\begin{abstract}
De novo synthesis in the central nervous system of IgG antibodies to human T cell lymphotropic virus type III (HTLVIII) (lymphadenopathy associated virus) was shown in seven of 10 seropositive men who had syphilis but not the acquired immune deficiency syndrome (AIDS) or AIDS related complex. None of these men showed neurological symptoms when the serum and cerebrospinal fluid were collected. Pleocytosis was present in all 10. Of the seven men who showed evidence of intrathecal synthesis of antibodies, five had increased total concentrations of IgG and four had oligoclonal IgG bands in their cerebrospinal fluid. Oligoclonal bands were also present in one man who did not have any antibodies. Longitudinal study of one man showed that seroconversion preceded intrathecal synthesis of antibody specific to HTLV-III. The appearance of antibody in the cerebrospinal fluid was accompanied by a transient rise in mononuclear cell count and the appearance of oligoclonal bands.

The presence of clones of B cells specific to HTLV-III in the central nervous system of these patients without persisting neurological symptoms suggests that HTLV-III enters the central nervous system in the early stages of infection.
\end{abstract}

Department of Virology, Academic Medical Centre, University of Amsterdam, The Netherlands

J GOUDSMIT, MD, PHD, virologist

M BAKKER, technician

L SMIT, technician

J VAN DER NOORDAA, MD, PHD, virologist and head of department

Department of Neurology, Academic Hospital, Vrije University of Amsterdam, The Netherlands

E C WOLTERS, MD, PHD, neurologist

Department of Neurology and Clinical Chemistry, Academic Medical Centre, University of Amsterdam, The Netherlands

E A H HISCHE, technician

J A TUTUARIMA, technician

H J VAN DER HELM, PHD, clinical chemist and head of department

Correspondence to: Dr J Goudsmit, Department of Virology, L1-153, Academic Medical Centre, Meibergdreef 15, 1105 AZ Amsterdam, Netherlands.

\section{Introduction}

Generalised encephalopathy resulting in dementia is a dominant feature of the acquired immune deficiency syndrome (AIDS), ${ }^{1}$ and human T cell lymphotropic virus type III (HTLV-III) (lymphadenopathy associated virus) has been implicated as the cause. ${ }^{2}$ HTLV-III has been isolated directly from the brain and cerebrospinal fluid of patients with and without AIDS. ${ }^{3}$ Intrathecal synthesis of antibodies to HTLV-III has been described in patients with AIDS and AIDS related complex. ${ }^{4}$ We describe intrathecal synthesis of IgG antibodies to HTLV-III in patients who did not have apparent neurological symptoms when the fluids were collected.

\section{Patients and methods}

SERUM AND CEREBROSPINAL FLUID

Matched serum and cerebrospinal fluid were obtained in 1984-5 from 74 homosexual men participating in a study on the occurrence of neurosyphilis. Sixty four did not have antibodies to HTLV-III in their serum and cerebrospinal fluid and were excluded from further analysis. The remaining 10 asymptomatic seropositive men were studied in detail. Samples of serum and cerebrospinal fluid were collected on the same day and frozen at $-20^{\circ} \mathrm{C}$. The collections were made during or after treatment of confirmed syphilis with high dose penicillin except in two patients (cases 9 and 10), who had early syphilis and had not yet been treated.

The Treponema pallidum haemagglutination assay showed that antibodies to $T$ pallidum were present in the serum of all 10 patients and in the cerebrospinal fluid of eight. Intrathecal synthesis of antibody to $T$ pallidum was evident in six patients (cases 1-5 and 9) from increased antibody indices. Increased numbers $(>5 / \mu \mathrm{l})$ of mononuclear cells were also present in all 10 patients. The cell counts were performed in triplicate with a FuchsRosenthal counting chamber.

\section{ANTIBODIES TO HTLV-III AND HEPATITIS B SURFACE ANTIGEN}

An enzyme linked immunosorbent assay with purified HTLV-III as the antigen (Vironostika, Organon, The Netherlands) was used to confirm the presence of antibodies to HTLV-III. Antibody titres were determined by testing twofold dilutions of serum and cerebrospinal fluid and were taken to be the dilution at which the logarithm corresponded to half the sum of the maximum and minimum optical densities at $450 \mathrm{~nm}$. 
Specificity for HTLV-III was confirmed by immunoblotting and was performed as follows. HTLV-III that had been purified on a sucrose gradient and inactivated by Triton X-100 (final concentration 1\%) and heat treatment $\left(60\right.$ minutes at $\left.56^{\circ} \mathrm{C}\right)$ was denatured by boiling for two minutes in $0.5 \mathrm{M}$ trometamol (TRIS) hydrochloric acid ( $\mathrm{pH} \mathrm{6.8)}$ containing $10 \%$ sodium dodecyl sulphate and $5 \% \beta$ mercaptoethanol. Viral proteins were separated on a $12 \%$ sodium dodecyl sulphate polyacrylamide gel and transferred to nitrocellulose paper. After washing at room temperature the paper was cut into strips and preincubated for 60 minutes at $37^{\circ} \mathrm{C}$ with normal goat serum. The strips were then incubated at room temperature with a test serum (dilution 1/100) and cerebrospinal fluid (dilution 1/25) before being washed again. Protein recognition patterns were visualised by incubating the strips first with biotinylated goat antihuman IgG and then with a complex of avidin and biotinylated horseradish peroxidase; colour was developed using 4-chloro-1-naphthol as substrate.

Antibodies to hepatitis $B$ surface antigen were determined by enzyme linked immunosorbent assay (AUSAB EIA, Abbott, USA).

\section{CRITERIA FOR INTRATHECAL SYNTHESIS OF TOTAL AND VIRUS SPECIFIC IgG}

Titres and recognition patterns of IgG specific to HTLV-III as well as total IgG and albumin concentrations were determined in matched samples of serum and cerebrospinal fluid. An increased ratio of antibody to albumin concentration (ratio of cerebrospinal fluid to serum concentrations of IgG specific to HTLV-III divided by the ratio of cerebrospinal fluid to serum concentrations of albumin) was considered to be evidence of intrathecal synthesis of viral antibody. The cut off value for the antibody:albumin ratio was $2 \cdot 0 .{ }^{5} \mathrm{An}$ increased IgG:albumin ratio (ratio of cerebrospinal fluid to serum concentrations of total IgG divided by the ratio of cerebrospinal fluid to serum concentrations of albumin) was considered to be evidence of intrathecal synthesis of IgG (upper normal limit 0.6$).^{78}$ The ratio of cerebrospinal fluid to serum albumin concentration was used to asssess the blood-brain barrier for protein (upper normal limit $7 \cdot 8 \times 10^{-3}$ ). Total IgG and albumin concentrations in serum and cerebrospinal fluid were determined with Cobas Bio centrifugal analysers. ${ }^{9}$ Cellulose acetate electrophoresis was used to show oligoclonal IgG bands, which are defined as IgG bands found exclusively in cerebrospinal fluid. ${ }^{10}$

\section{Results}

IgG antibodies to HTLV-III were detected in cerebrospinal fluid from seven of the 10 seropositive homosexual men. Figure 1 shows typical IgG recognition patterns of HTLV-III in serum and cerebrospinal fluid, the proteins recognised being predominantly $\mathrm{p} 24, \mathrm{p} 51$, and $\mathrm{p} 65$. In some cases the viral proteins gp4l and gp110 were also recognised. No extra bands were seen in cerebrospinal fluid relative to serum. Table I shows antibody titres to HTLV-III in serum and cerebrospinal fluid; titres ranged from 35 to 279 in serum compared with $0-23$ in cerebrospinal fluid.

Intrathecal synthesis of IgG specific to HTLV-III was shown in all seven asymptomatic homosexuals with antibodies by increased antibody:albumin ratios (table I). Oligoclonal IgG bands in cerebrospinal fluid were shown in four of these seven patients but in only one of the three patients without antibodies. None of these lumbar punctures had been traumatic as no erythrocytes were present in the cerebrospinal fluid samples. The bloodbrain barrier was intact for protein in all patients seropositive for HTLV-III as determined by ratios of cerebrospinal fluid to serum albumin concentrations (table I). Increased total IgG concentrations were present in cerebrospinal fluid from five of the seven homosexual men with antibody to HTLVIII.

Antibodies to hepatitis B surface antigen (anti-HBs) were measured in the serum and cerebrospinal fluid of patients seropositive for HTLV-III. In three of the five patients who had anti-HBs in their serum no anti-HBs was detected in the cerebrospinal fluid. In one patient (case 2) the anti HBs titre was $21360 \mathrm{IU} / \mathrm{ml}$ in serum and $70 \mathrm{IU} / \mathrm{ml}$ in cerebrospinal fluid; in case 4 the titre was $5722 \mathrm{IU} / \mathrm{ml}$ in serum and $14 \mathrm{IU} / \mathrm{ml}$ in cerebrospinal fluid. The antibody ratios for anti $\operatorname{HBs}(0 \cdot 3$ and $0 \cdot 1$ respectively) did not exceed the cut off value of $2 \cdot 0$.

Serum and cerebrospinal fluid samples were available from one man (case 2) who seroconverted for HTLV-III and remained healthy three years after seroconversion (table II). Antibodies to HTLV-III in his cerebrospinal fluid became detectable by enzyme linked immunosorbent assay five months after seroconversion, and the titre continued to rise (fig 2). The immunoblot analysis confirmed these results. Antibodies in cerebrospinal fluid reacted to only the major structural protein $\mathrm{p} 24$, while antibodies in the serum reacted with p24, gp41, p51, and p65 (fig 3). The antibody: albumin ratio steadily increased over time while the blood-brain barrier for protein remained intact. When the antibody:albumin ratio started to rise a concomitant rise in total IgG concentration relative to albumin concentration was observed. Oligoclonal IgG bands appeared in the cerebrospinal fluid concomitantly with antibodies specific to HTLV-III (table II), and a transient rise in mononuclear cells in the cerebrospinal fluid was observed. The appearance of oligoclonal bands in the cerebrospinal fluid was not accompanied by a change in the index of antibody to $T$ pallidum; intrathecally synthesised antibody to this micro-organism was present in the cerebrospinal fluid at each date shown in table II. This patient was treated for syphilis from 24 January to 9 February 1983.

\section{Discussion}

Our results parallel those found in the cerebrospinal fluid of sheep infected with visna virus. ${ }^{11}$ Examination of the cerebrospinal fluid of such sheep showed antiviral antibody whether the animal had clinical evidence of neurological disease or not. ${ }^{12}$ Antibodies to visna virus in the cerebrospinal fluid seemed to be produced intrathecally,

TABLE I-Titres in serum and cerebrospinal fluid of IgG antibody HTLV-III, antibody ratios, and oligoclonal IgG bands in 10 seropositive asymptomatic men

\begin{tabular}{|c|c|c|c|c|c|c|c|c|}
\hline \multirow[b]{2}{*}{ Case No } & \multirow{2}{*}{$\begin{array}{c}\text { Age } \\
\text { (years) }\end{array}$} & \multicolumn{2}{|c|}{ Titre of IgG antibody to HTLV-III } & \multirow{2}{*}{$\begin{array}{l}\text { Antibody: } \\
\text { albumin ratio }\end{array}$} & \multirow{2}{*}{$\begin{array}{l}\text { IgG: albumin } \\
\text { ratio }\end{array}$} & \multirow{2}{*}{$\begin{array}{l}\text { Oligoclonal IgG } \\
\text { bands in } \\
\text { cerebrospinal fluid }\end{array}$} & \multirow{2}{*}{$\begin{array}{l}\text { Cerebrospinal fluid: serum } \\
\text { albumin }\left(\times 10^{-3}\right)\end{array}$} & \multirow{2}{*}{$\begin{array}{l}\text { Mononuclea } \\
\text { cells } / \mu \mathrm{l}\end{array}$} \\
\hline & & Serum & Cerebrospinal fluid & & & & & \\
\hline 1 & 38 & 98 & 4 & $6 \cdot 6$ & 0.6 & - & $6 \cdot 2$ & $10 \cdot 7$ \\
\hline 2 & 52 & 280 & 8 & 3.8 & 0.7 & + & 7.5 & $13 \cdot 7$ \\
\hline 3 & 39 & 43 & 0 & 0 & 0.5 & + & $5 \cdot 2$ & $7 \cdot 3$ \\
\hline 4 & 30 & 139 & 17 & $25 \cdot 4$ & 0.8 & + & $4 \cdot 8$ & $15 \cdot 7$ \\
\hline 5 & 53 & 92 & 3 & $9 \cdot 0$ & 0.7 & + & 3.6 & $5 \cdot 3$ \\
\hline 6 & 29 & 80 & 0 & 0 & 0.5 & - & $5 \cdot 3$ & $16 \cdot 3$ \\
\hline 7 & 34 & 61 & 0 & 0 & 0.6 & - & 3.4 & $5 \cdot 3$ \\
\hline 8 & 31 & 113 & 4 & $8 \cdot 4$ & 0.7 & - & $4 \cdot 3$ & 6 \\
\hline 9 & 42 & 40 & 3 & $16 \cdot 8$ & 0.6 & + & 3.7 & $6 \cdot 3$ \\
\hline 10 & 39 & 35 & 4 & 26.8 & 0.8 & - & $4 \cdot 4$ & $21 \cdot 3$ \\
\hline
\end{tabular}

TABLE II-Titres of IgG antibody to HTLV-III in serum and cerebrospinal fluid, antibody ratios, and oligoclonal IgG bands in a seroconverted homosexual man

\begin{tabular}{|c|c|c|c|c|c|c|c|}
\hline \multirow[b]{2}{*}{ Date } & \multicolumn{2}{|c|}{ Titre of IgG antibody to HTLV-III } & \multirow{2}{*}{$\begin{array}{l}\text { Antibody: } \\
\text { albumin ratio }\end{array}$} & \multirow{2}{*}{$\begin{array}{l}\text { IgG: albumin } \\
\text { ratio }\end{array}$} & \multirow{2}{*}{$\begin{array}{l}\text { Oligoclonal IgG } \\
\text { bands in } \\
\text { cerebrospinal fluid }\end{array}$} & \multirow{2}{*}{$\begin{array}{l}\text { Cerebrospinal fluid: serum } \\
\text { albumin }\left(\times 10^{-3}\right)\end{array}$} & \multirow{2}{*}{$\begin{array}{l}\text { Mononuclear } \\
\text { cells } / \mu \mathrm{l}\end{array}$} \\
\hline & Serum & Cerebrospinal fluid & & & & & \\
\hline $\begin{array}{l}\text { 30 November } 1982 \\
2 \text { August } 1983 \\
14 \text { February } 1984 \\
10 \text { May } 1984 \\
9 \text { May } 1985\end{array}$ & $\begin{array}{r}0 \\
140 \\
280 \\
211 \\
280\end{array}$ & $\begin{array}{r}0 \\
0 \\
8 \\
12 \\
23\end{array}$ & $\begin{array}{r}0 \\
0 \\
3 \cdot 8 \\
7 \cdot 4 \\
12 \cdot 9\end{array}$ & $\begin{array}{l}0.80 \\
0.82 \\
0 \cdot 74 \\
0 \cdot 86 \\
0.95\end{array}$ & $\begin{array}{l}- \\
- \\
+ \\
+ \\
+\end{array}$ & $\begin{array}{l}6 \cdot 7 \\
7 \cdot 5 \\
7 \cdot 5 \\
7 \cdot 6 \\
6 \cdot 4\end{array}$ & $\begin{array}{r}8 \cdot 7 \\
9 \cdot 3 \\
13 \cdot 7 \\
5 \cdot 7 \\
6 \cdot 0\end{array}$ \\
\hline
\end{tabular}


and a concomitant rise in total IgG compared with extrathecally produced protein was seen. ${ }^{11}$ Intrathecal production of antibodies to HTLV-III in the cerebrospinal fluid of seropositive patients depends on when the virus enters the central nervous system and patients and so cannot be considered to be specific for infection with HTLV-III.

Antibody to HTLV-III synthesised intrathecally might either reflect residual $B$ cell reactivity without persistent antigenic stimula-

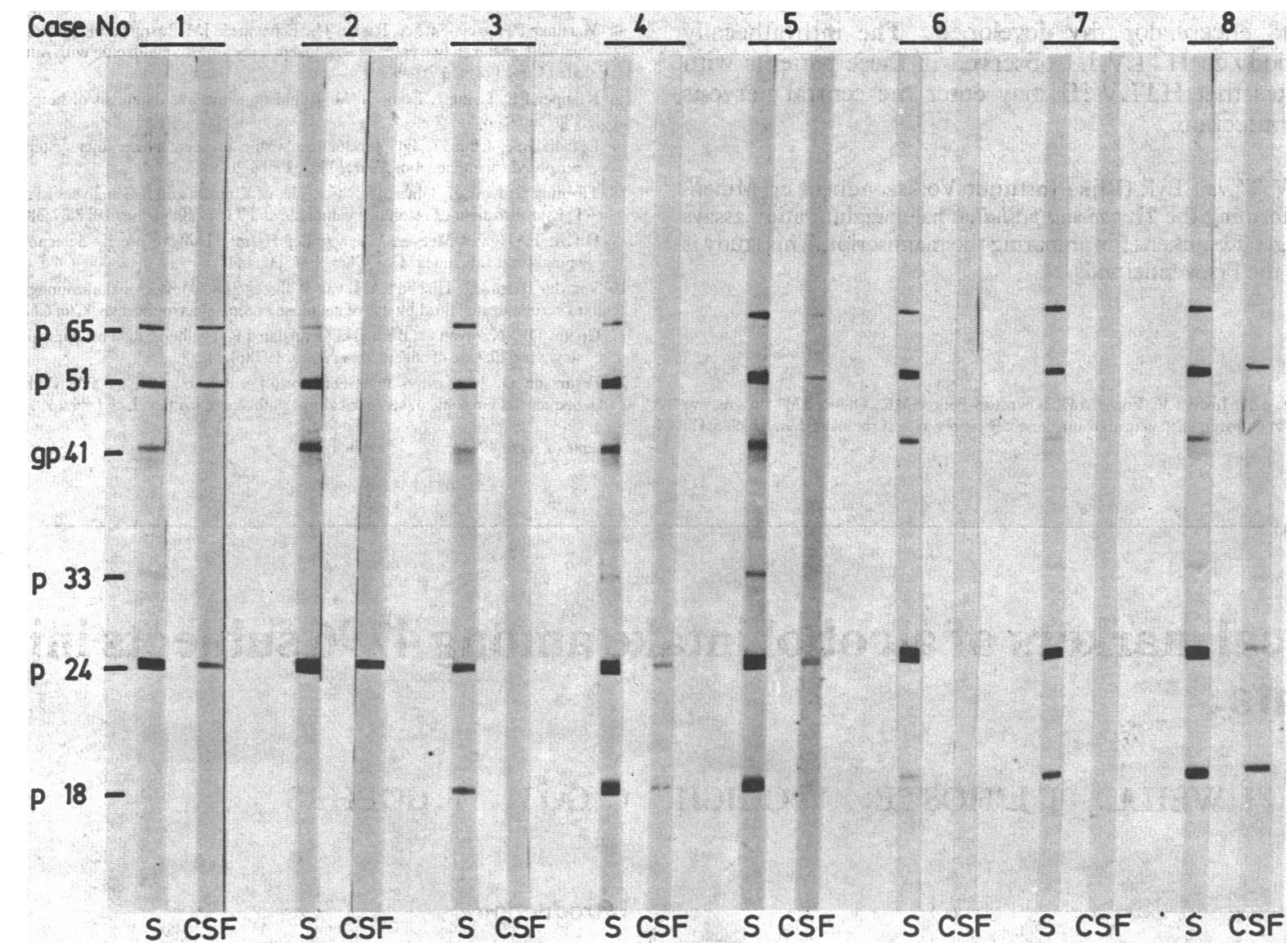

FIG $1-\operatorname{IgG}$ recognition patterns of HTLV-III in serum $(S)$ and cerebrospinal fluid $(\mathrm{CSF}$ ) of asymptomatic homosexual men (cases 1 8). Viral proteins with their relative molecular mass are indicated on the left.

may vary considerably between patients. The ratio of cerebrospinal fluid to serum titres of HTLV-III antibodies indicates the presence of B cell clones specific to HTLV-III in the central nervous system of patients without apparent neurological symptoms; transient neurological symptoms present around the time of seroconversion could not be assessed retrospectively. Oligoclonal bands and pleocytosis were present in both seropositive and seronegative

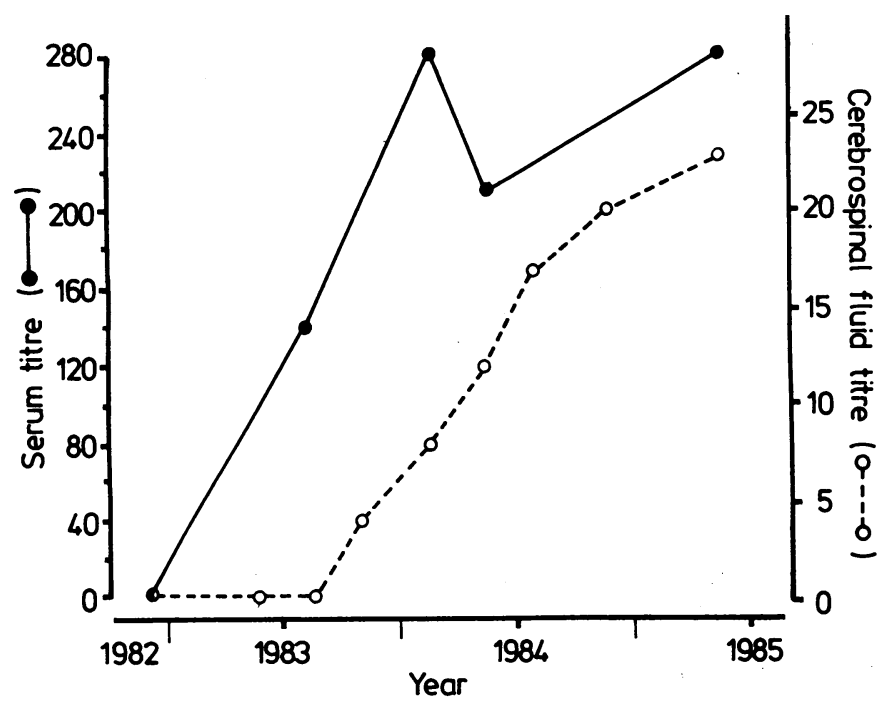

FIG 2-Titres of IgG antibody to HTLV-III in serum and cerebrospinal fluid from seroconverted asymptomatic homosexual man (case 2 ).

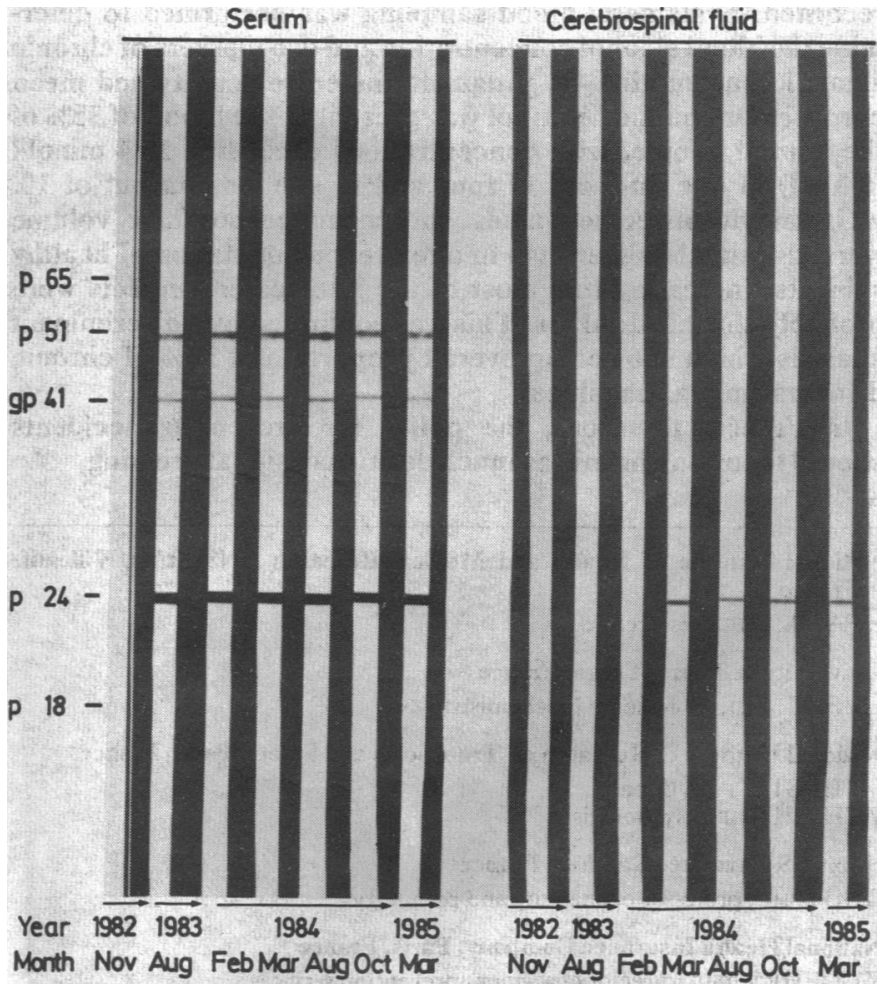

FIG 3-Temporal development of IgG recognition patterns of HTLV-III in serum and cerebrospinal fluid from seroconverted asymptomatic homosexual man. Viral proteins with their relative molecular mass are indicated on the left. 
tion of the central nervous system or be direct evidence of active infection of the central nervous system. To solve the issue of active infection of the brain in early infection with HTLV-III virus or viral antigens must be shown to be present in the cerebrospinal fluid. Levy et al reported that active replication of HTLV-III occurred within the central nervous system before clinical signs of AIDS or AIDS encephalopathy developed. ${ }^{3}$ The inthrathecally produced antibody to HTLV-III observed in these patients with syphilis indicates that HTLV-III may enter the central nervous system early in infection.

We thank R V W van Eyk (Rijks Instituut Volkszondheid en Milieuhygiene) for performing the Treponema pallidum haemagglutination assays and Riet de Krieger-Reumkens for preparing the manuscript. This study is partly funded by the Praeventiefonds.

\section{References}

1 Epstein LG, Sharer LR, Joshi VV, Fojas MM, Koenings-berger MR, Oleske JM. Progressive encephalopathy in children with acquired immune deficiency syndrome. Ann Neurol 1985;17: 488-96.
2 Shaw GM, Harper ME, Hahn BH, et al. HTLV-III infection in brains of children and adults with AIDS encephalopathy. Science 1985;227:177-82.

3 Levy JA, Shimabukuro J, Hollander H, Mills J, Kaminsky L. Isolation of AIDS-associated retrovirus from cerebrospinal fluid and brain of patients with neurological symptoms. Lance 1985; ii:580-6.

4 Resnick L, diMarzo-Veronese F, Schupbach J, et al. Intra blood-brain-barrier synthesis of HTLV-III-specific IgG in patients with neurologic symptoms associated with AIDS or AIDS related complex. N Engl f Med 1985;313:1498-504

5 Martinez P, Carcia-Saiz A, Rapun JL, Echevarria JM. Intrathecal synthesis of IgG antibodies to varicellazoster in two cases of acute aseptic meningitis syndrome with mucocutaneous lesions. $\mathcal{f}$ Med Virol 1985;16:201-9.

6 Klapper PE Laing It Longson M. Rapid non-invasive diagnosis of herpes encephalisis. Lance $1981 ;$ ii:607-9.

Lefvert AK, Link H. IgG production within the central nervous system: a critical review of proposed formulae. Ann Neurol 1985;17:13-20.

8 Tibbling G, Link H, Ohman S. Principles of albumin and IgG analyses in neurological disorders. I. Establishment of reference values. Scand f Clin Lab Invest 1977;37:385-90.

9 Hische EAH, van Meegen MT, van der Helm HJ. More precise determination of the cerebrospinal fluid IgG index. Clin Chem 1985;31:1417.

10 Van der Helm HJ, Hische EAH, van Walbeek HK. Monoclonal immunoglobulins demonstrable in cerebrospinal fluid by use of cellulose acetate electrophoresis. Clin Chem 1980;26:1917-8.

11 Griffin DE, Narayan O, Bulowski JF, Adams RJ, Cohen SR. The cerebrospinal fluid in visna, slow viral disease of sheep. Ann Neurol 1978:4:212-8.

12 Petursson G, Nathanson N, Georgsson, Panitch H, Palsson PA. Pathogenesis of visna. I. Sequential virological, serological and pathologic studies. Lab Invest 1976;35:402-12.

(Accepted l April 1986)

\title{
Biological markers of alcohol intake among 4796 subjects injured in accidents
}

\author{
L PAPOZ, J WEILL, J L'HOSTE, Y CHICH, C GOT, Y GOEHRS
}

\begin{abstract}
An epidemiological survey was carried out in France in 1982-3 to study the proportions of occasional and chronic drinkers among people injured in accidents of all kinds. The characteristics of 4796 victims recruited in the emergency units of 21 hospitals were recorded. Systematic blood sampling was performed to determine the blood alcohol concentration and two markers of chronic alcohol consumption- $\gamma$-glutamyltransferase activity and mean corpuscular volume. Alcohol was present in the blood of $35 \%$ of the injured people, with concentrations exceeding $17.4 \mathrm{mmol} / \mathrm{l}$ $(0.8 \mathrm{~g} / 1)$ in one man out of four and in one woman out of 10 . $\gamma$-Glutamyltransferase values and mean corpuscular volume were also much higher than in a reference population of healthy subjects, indicating that most of the intoxicated subjects were probably chronic drinkers. This was confirmed by a discriminant analysis which showed an overall proportion of $30 \%$ of chronic drinkers among casualties.
\end{abstract}

In France, therefore, the policy for preventing accidents should focus on chronic as much as on occasional drinking.

National Institute of Health and Medical Research (INSERM), Villejuif, France

L PAPOZ, PHD, research fellow

University of Tours, Tours, France

J WEILL, MD, professor of biochemistry

National Institute of Research on Transports and Safety, Paris, France J L'HOSTE, PHD, director

Y CHICH, PHD, psychologist

Hôpital R Poincaré, Garches, France

C GOT, MD, professor of anatomy and pathology

National Health Insurance Company, Paris, France

Y GOEHRS, PHD, director of accident prevention services

Correspondence and requests for reprints to: Dr Papoz, INSERM Unité 21 16 Avenue Paul Vaillant Couturier, 94807 Villejuif Cedex, France.

\section{Introduction}

Traffic accidents are known to be strongly associated with alcoholic intoxication, so many countries enforce a legal limit on the blood alcohol concentration of drivers. Epidemiological studies have so far been mostly based on blood or breath alcohol values measured at the time of the accident. ${ }^{1-6}$ Only a few authors have tried to evaluate to what extent the presence of alcohol in the blood might be related to chronic heavy drinking (Pikkarainen J, Pentilla A, 8th International Conference on Alcohol, Drugs, and Traffic Safety, Stockholm 1980)..$^{7.9}$

Nevertheless, the knowledge of this relation, if any, might be of paramount importance in optimising preventive action against accidents. This is particularly true in France, where alcohol consumption remains one of the highest in the world ${ }^{10}$ and where traffic accidents are the major cause of premature death, leading to about 11000 deaths each year. ${ }^{11}$ Furthermore, alcohol consumption is likely to play a part in other kinds of accidents occurring at home, at work, or during leisure or sport activities.

To tackle these problems a nationwide epidemiological survey was started in 1982, at the Prime Minister's request, to assess the proportions of occasional and chronic heavy drinkers concerned in accidents. It was decided to measure systematically, in addition to the blood alcohol concentration, the $\gamma$-glutamyltransferase activity and the mean corpuscular volume, both of which, alone ${ }^{1213}$ and in combination, ${ }^{14}$ correlate reasonably well with usual alcohol intake.

\section{Population and methods}

\section{POPULATION}

The subjects were recruited from October 1982 to March 1983 in the emergency units of 21 hospitals, two in Paris and the other 19 in towns all over France. In each centre the study schedule was planned so that each day of the week and each hour of the day were equally represented.

The criteria for inclusion were: $(a)$ that the subject presented, with or without apparent injury, after an accident of any kind, including traffic accidents, accidents at work, in the home, or during leisure or sporting 